\title{
Estimating Tourism Import Demand Elasticities for Four Countries Using the General-to-specific Approach
}

\author{
Ibrahim Mohammed \\ University of Professional Studies, Accra
}

This paper applied the general-to-specific econometric modelling technique to estimate demand for tourism imports and the corresponding elasticities for four countries: Australia; Canada; Japan and USA. The findings indicate that tourism imports are generally income and price elastic with values ranging from 1.476 to 1.783 for income elasticity and -1.201 to -1.721 for price elasticity. Furthermore, the findings reveal that, after controlling for seasonality in the data, demand for tourism import is influenced by global financial crisis, disasters and country-specific problems. These findings have important implications for tourism import management, especially in the broader context of promoting tourism imports.

\section{INTRODUCTION}

Over the past decades, the tourism industry has been developing rapidly and contributing significantly to economic growth, especially in tourism-intensive countries (Martins, Gan, \& Ferreira-Lopes, 2017). As a non-physical commodity, tourism is traded domestically or internationally. At the international level, trade in tourism is treated as an export (inbound) or import (outbound) depending on the country that is receiving or generating the tourists. Since the end of the World War II, international tourism demand has grown rapidly (Crouch, 1995), making it important for academic researchers and industry practitioners to be interested in the factors that influence demand for tourism (e.g. Martins, Gan \& Ferreira-Lopes, 2017; Tang \& Tan, 2016; Tavares \& Leitão, 2017; Lorde, Li \& Airey, 2016; Song \& Li, 2008; Crouch, 1994). Between 1960 and 1983, Crouch (1994) identified 80 research articles that were published on international tourism demand. In another review paper, Song and Li (2008) identified more than 150 publications on tourism demand that were published between the period of 2000 and 2007. Strikingly, the vast majority of the studies have been concerned with estimating demand elasticities and forecasting tourists flow. A key motivation for the concentration of studies on demand elasticities and forecasting is that their results are needed for policy formulation and investment decision-making. Thus, the volume of research on tourism demand notwithstanding, researchers in this field cannot be accused of overindulgence because the estimates change from time to time, and therefore need to be recalculated and verified periodically.

Besides, a closer examination of the extant literature on tourism demand also reveals trends that create opportunities for further research. First, the literature is dominated by studies on international inbound (export) tourism demand with limited studies on demand for outbound (import) tourism (Seetaram, 2012a; 2012b; Cortés-Jiménez, 2009; Lim, Min \& McAleer, 2008; Song, Romilly \& Liu, 2000). This situation has been attributed to the lack of consistent data on outbound tourism and the 
perception that inbound tourism is considered to be more important for economic development (Seetaram, 2012a). Meanwhile, for tourism demand studies to be balanced, an appreciable number of studies need to be conducted on outbound tourism, especially demand elasticities. Such studies can provide valuable inputs to complement policy formulation in the broader context of promoting or discouraging imports. Furthermore, knowledge of tourism import demand elasticities can benefit local tourism business since domestic tourism is regarded as the closest substitute for outbound tourism (Song \& Witt, 2000; Seetaram, 2012a).

The second trend identified from the extant literature which paves way for further research is the limited studies conducted on outbound tourism demand modelling relative to inbound tourism demand modelling. The focus of these studies has been on a single country (e.g. Pham, Nghiem \& Dwyer, 2017; Seetaram, 2012a; 2012b; Cortés-Jiménez, 2009; Lim, Min \& McAleer, 2008; Song, Romilly \& Liu, 2000) with majority of them using the Almost Ideal Demand System (AIDS) developed by Deaton and Muellbauer (1980), or one of its variations, and therefore providing limited information on the range of demand elasticities. In a departure from these studies, Smeral (2012), has analysed tourism imports generated by USA, Japan, Canada, Australia and the European region to show that changes in real GDP and tourism import price index significantly influence changes in real tourism import. While Smeral's (2012) study contributes fresh insights into how tourism import demands are responsive to business cycles, the ability of the models to capture short-term variations or seasonality in tourism demand is compromised since annual data were used. However, as demonstrated by other studies (e.g. Lim, 2004), these short-term variations are important and need to be explicitly recognized.

In view of the aforementioned shortfalls, this study seeks to provide estimates of tourism import demand elasticities to complement Smeral's (2012) study by accounting for short-term seasonal variation in the data. As a departure from Smeral's (2012) study, the current study also employs the general-tospecific econometric modelling involving Autoregressive Distributed Lag Model (ADLM). This methodology is argued to be more appropriate for modelling tourism demand given its ability to capture dynamic behaviour in tourism (Song \& Witt, 2000; 2003). It has been applied by Ayeh and Lin (2011) and found to demonstrate goodness of fit indices.

The remainder of the paper is organised as follows. The next section presents the literature review on outbound tourism studies and the underlying theory of demand. This is followed by an econometric specification of the demand function and a brief description of the general-to-specific modelling technique. The estimated tourism demand models together with the associated demand elasticities are subsequently presented and discussed. The final section presents the conclusions and implications of the findings.

\section{LITERATURE REVIEW}

\section{Tourism Demand}

Generally, tourism demand is usually distinguished in terms of domestic (i.e. within country travel for tourism purposes) and international tourism (i.e. travel to other countries for tourism purposes) (EugenioMartin \& Campos-Soria, 2011; Song \& Li, 2008; Agnew \& Palutikof, 2006). With regards to international tourism, another distinction that is worth emphasizing is the difference between international inbound tourism (also known as tourism export or international arrivals) and international outbound tourism (alternatively known as tourism import or international departures) (Seetaram, 2012a). At the macro level, international inbound tourism is considered to be a source of injection of resources into an economy, while outbound tourism is viewed as a source of leakage or a drain to an economy.

Of the two types of international tourism, international inbound tourism (or tourism export) has attracted a great deal of attention. The reasons adduced for this imbalance are many but Seetaram (2012a), suggests that international outbound tourism has not been able to generate an equivalent amount of research interest as inbound tourism demand because there is a perception that inbound tourism is more important than outbound tourism. The justification being that inbound tourism injects resource into the 
receiving country by way of foreign exchange, tax revenue and employment creation while outbound tourism causes leakage of resources.

However, there are equally important reasons why international outbound tourism should be given a deserving attention. First, it is argued that tourism businesses such as travel and tour operators, airlines, airports and domestic transport operators benefit from the expansion in the international outbound tourism market (Seetaram, 2012a). Second, international outbound tourism may be regarded as a close substitute for the domestic tourism industry (Crouch, 1994) and therefore information on tourism import will be useful to local tourism business in making their pricing and supply decisions (Seetaram, 2012a). Finally, international outbound tourism forms part of the import of a country and the travel industry and therefore research on international outbound tourism can provide valuable inputs for policy formulation and analysis. Thus, as a contribution to the scant literature on international outbound tourism, this paper seeks to close this gap between international inbound and outbound studies.

\section{Determinants of Tourism Import Demand}

Existing literature on tourism demand portrays a number of factors as influencing demand for tourism. These factors have been classified into three groups by Mikulicz (1983) as factors that determine the market volume (e.g. population, income, leisure time, education, occupation etc.), factors that determine the cost of travel (e.g. fares, distance and time; and the cost of tourist services including the impact of inflation and exchange rates), and factors that determine the utility or image of the destination (such as tourist appeal, publicity, information, weather, language, ancestry, etc.). In an earlier study, Vanhove (1980) also categorized the determinants of tourism demand into four mutually exclusive groups. The first is the market element which refers to the factors that determine the overall number of trips. The second is the destination elements which includes attributes of the destination that attract or deter tourist. The third is the location elements which define the geographic relationship between the destination and the market. The last group is the ties elements which refers to the factors that represent business, cultural, and other links between countries.

As far as econometric modelling of tourism demand is concerned, the standard demand theory in economics is frequently invoked. This theory assigns a central role to income and price as the main determinants of demand. The results from previous studies (e.g. Lim, 1997; Song \& Witt, 2000, Ayeh \& Lin, 2011; Smeral, 2009; 2012; Song \& Witt, 2003; Song, Wong \& Chon, 2003) have confirmed that income and prices are the most significant explanatory variables in tourism demand modelling. Indeed, some of the studies have found that economic determinants alone account for much of the variation in tourist number and expenditure (Crouch, 1994). In view of this, price and income will be considered in this study as the two major determinants of demand and the coefficients of these variables will determine price and income elasticities of demand respectively.

\section{Effects of Price and Income on Tourism Import Demand}

In the standard demand theory, the effects of price and income on demand generally depend on the type of good. Going by the law of demand, price is expected to have a negative influence on demand all else being equal. However, in some exceptional cases, where a product is considered to be a Giffen good, price can have a positive influence on demand. With reference to tourism import demand, a Giffen good scenario is less likely due to the expectations that the positive income effect of a price change cannot outweigh the negative price substitution effect. Therefore, in this study it will be expected that price of tourism import will have a significant negative relationship with the tourism imports generated by a country. In the context of international tourism, an appropriate measure of price should include the foreign currency of price of tourist goods and services in the destination, the cost of transportation between the countries, and the effect of exchange rate variations on the purchasing power (Crouch, 1996).

In contrast to the effect of price, income is expected to have a positive influence on demand for a normal good but a negative influence on demand for an inferior good. In addition, the effect of income on normal goods is expected to be higher for luxury goods than necessities. With regards to tourism demand, there is a debate over which aggregate measure of income (real disposable income or real GDP) to use in 
the demand model. Some researchers (Kulendran \& Wilson, 2000; Song et al., 2003; Ayeh \& Lin, 2011) advocate the use of real disposable income when tourists consist of only leisure travellers and real GDP when business travellers are involved. The tourism data used in this study includes business travellers; hence, real GDP is used.

\section{Effects of other Factors on Tourism Import Demand}

In the tourism demand literature, other factors such as consumer taste and preferences, cost of transportation, marketing expenditure and destination image have also been recognized as potential determinants of tourism import demand (Song et al., 2003; Smeral, 2012). However, due to the difficulty in measuring some of these variables and the lack of consistent and longitudinal data, prior research has excluded them in tourism demand modelling without any consequential loss in the overall goodness of fit (Song et al., 2003; Ayeh \& Lin, 2011). For lack of data on these variables, the present study also excludes them. However, the complex nature of tourism requires the inclusion of variables that will capture the influences of seasonality and special events. In previous studies (e.g. Ayeh \& Lin, 2011; Smeral, 2009; 2010; Song \& Witt, 2003; Song et al., 2003), the effects of these special events and seasonality have been captured by the inclusion of dummy variables in the econometric modelling. Consistent with these studies, the current study also employs dummy variables to capture the effects of seasonality and one-off events on demand for outbound tourism.

\section{METHODOLOGY}

This section describes the research design that was adopted for this study, followed by the model specification and the estimation technique.

\section{Research Design}

The study design involved the use of quantitative methods to establish associations between the dependent variable and the set of independent variables. In particular, the explanatory research design involving multiple regression technique is employed. The multiple regression model is expressed as demand elasticities and they represent the percentage change in demand associated with a $1 \%$ change in the corresponding determinant. For example, a coefficient of 1.5 for income elasticity implies that a $1 \%$ increase income results in a $1.5 \%$ increase in tourism import demand and vice versa. A number of studies (e.g. Witt \& Witt, 1992; Song \& Witt, 2000; Song et al., 2003; Ayeh \& Lin, 2011) have also used similar design and has been found to be a useful technique for interpreting coefficients of the regression results.

\section{Model Specification and Data}

Following the standard demand theory and the convention in previous studies (Song et al., 2003; Ayeh \& Lin, 2011; Smeral, 2012), tourism import demand for any given country is modelled primarily as a function of aggregate income and price.

$R T M_{t}=f\left(R G D P_{t}, R T M P_{t}\right)$

where: $\mathrm{RTM}_{\mathrm{t}}$ is real tourism import generated by a given country at time $t$ (in US\$ Million); RGDP is the real gross domestic product of that country at time $t$ (in US\$ Million); and $\mathrm{RTMP}_{\mathrm{t}}$ is the relative tourism import price for that country at time $t$ computed as follows:

$$
R T M P_{t}=\frac{T M P_{t}}{G D P D_{t}} ;
$$

and $\mathrm{TMP}_{\mathrm{t}}$ and $\mathrm{GDPD}_{\mathrm{t}}$ are tourism import price index and GDP deflator at time $t$ respectively.

To obtain the parameter estimates for the demand function (1), the power function is adopted to specify the econometric model in equation (2). This specification has been found by previous studies to 
be a better way of modelling tourism demand to achieve statistical significance and forecasting accuracy (Witt \& Witt, 1992; Song \& Witt, 2000; Song et al., 2003; Ayeh \& Lin, 2011).

$R T M_{t}=A\left(R G D P_{t}\right)^{\gamma_{1}}\left(R T M P_{t}\right)^{\gamma_{2}} \varepsilon_{t}$

where $\varepsilon_{t}$ is the random error term assumed to be normally distributed with zero mean and constant variance; that is $\varepsilon_{t} \sim N\left(0, \sigma^{2}\right)$

For the purposes of estimating the parameters and calculating the elasticities, the power function is transformed by taking natural logarithms of the two sides of the equation (2) (i.e. log-log transformation). The log-log transformation allows the coefficients of the relevant respective demand variables to be interpreted directly as partial elasticities of demand (Witt \& Witt, 1992).

$\ln R T M_{t}=\gamma_{0}+\gamma_{1} \ln R G D P_{t}+\gamma_{2} \ln R T M P_{t}+\mu_{t}$

where: $\gamma_{0}=\ln A, \mu_{t}=\ln \varepsilon_{t}$, and $\gamma_{1}$ and $\gamma_{2}$ are income and price elasticities respectively. Based on demand theory and the conviction that tourism is a normal good, it is expected that $\gamma_{1}>0$ and $\gamma_{2}<0$

Equation (3) describes a static demand model for tourism import which does not reflect the time lag in tourists' decision-making process. To reflect the dynamic nature of tourism product, the Autoregressive Distributed Lag Model (ADLM), first introduced into tourism demand modelling by Song and Witt (2000) and subsequently adopted by Song and Witt (2003), Song et al. (2003), Ayeh and Lin (2011) is applied to specify equation (4).

$\operatorname{lnRTM}_{t}=\gamma_{0}+\alpha_{j} \sum_{j=1}^{4} \operatorname{lnRTM_{t-j}}+\beta_{j} \sum_{j=0}^{4} \ln R G D P_{t-j}+\delta_{j} \sum_{j=0}^{4} \operatorname{lnRTMP_{t-j}}+$ dummies $+\mu_{t}$

The number of lags for each variable in equation (4) is normally decided by using Akaike Information Criterion (AIC) or the Bayesian Information Criterion (BIC). However, the general rule of choosing 4 lags for quarterly data is followed. The lags of the dependent variable have been included on the righthand side of the model to reflect the argument that tourism demand is influenced by expectations and habit persistence (Song et al., 2003). In practice, not all the lags may influence demand and therefore the testing procedure adopted in this study will eliminate the statistically insignificant variable(s) and the variable(s) with incorrect or unacceptable signs.

Dummies are also included in equation (4) to capture seasonal variation in the data and the effects of one-off events. The dummies included comprise: three seasonal dummies, namely, $\mathrm{D}_{1}, \mathrm{D}_{2}$ and $\mathrm{D}_{3}$ for quarters 1, 2 and 3 respectively as well as three one-off event dummies, D01, D03 and D08 for the influence of September 11, 2001 terrorist attack on World Trade Centre, the 2003 outbreak of Severe Acute Respiratory Syndrome (SARS) in some Asian countries and the Global financial crisis of 2008 respectively. All the one-off events' dummies are expected to have negative effects on demand for outbound international tourism.

Equation (4) is estimated for Australia, Canada, Japan and USA. These countries are selected to be in line with Smeral's (2012) study so that the results will be comparable. Using similar data sources, the data for the estimation were obtained from the balance of payments statistics of International Monetary Fund (IMF), the national accounts of the Organization for Economic Co-ordination and Development (OECD) and the tourism statistics of the World Tourism Organization. All the models were estimated using quarterly data from the first quarter of 1977 to the first quarter of 2017.

\section{Estimation Technique}

The estimation technique applied in this study is the classical Ordinary Least Squares (OLS). This method has been the most widely-used approach. Its advantages include the ability of the model to establish cause and effect relationships, and to provide statistical measures of accuracy and significance (Crouch, 1994). In using this technique, a decision was made to use the general-to-specific approach (also 
known as the top-bottom approach) due to its superiority over the specific-to-general approach (Song \& Witt, 2003). This was a departure from Smeral's (2012) approach. The specific-to-general methodology has been criticised as heavily relying on data mining with no clear strategy but a tendency to produce spurious regression results (Witt \& Witt, 1992; Kulendran \& Witt, 2001).

As the first authors to demonstrate the use of general-to-specific approach in tourism demand modelling, Song and Witt (2003) describes the process as involving some steps which are summarized in Figure 1.

\section{FIGURE 1 \\ GENERAL-TO-SPECIFIC MODELLING PROCESS}

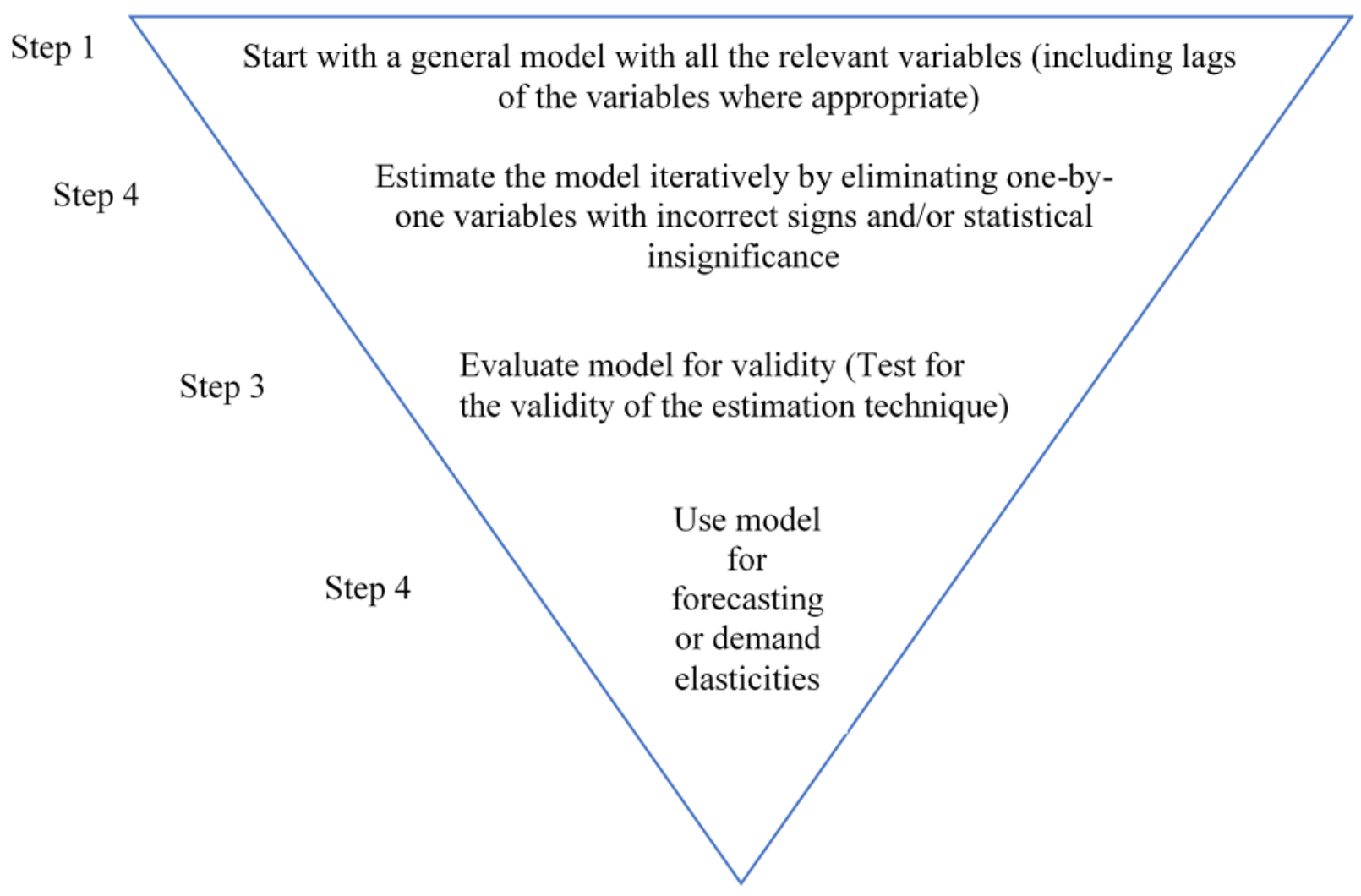

\section{RESULTS AND DISCUSSION}

\section{Estimates of the Parameter of Tourism Import Demand Model}

Table 1 presents the findings of the empirical analysis of the data following the general-to-specific approach outlined in Figure 1. Overall, the summary statistics of the 4 models indicate satisfactory results. The goodness of fit measures, $\mathrm{R}^{2}$ and adjusted $\mathrm{R}^{2}$, are more than 0.93 in all the models. These indicate that more than $93 \%$ of the variations in tourism import demand are explained by variations in the independent variables included in these models. The F-statistics also indicate that the predictor variables in each of the models are jointly significant in explaining demand for tourism import.

The coefficients of the income and price variables in all the four models are consistent with their theoretical predictions, both in terms of direction of effects (signs) and plausible magnitudes of the effects (sizes). The income and price variables are both significant at $1 \%$ level of significance confirming their importance as predictors of demand for tourism. Worthy of note in the results reported in Table 1 is also the significant effects of the lagged dependent variable in all the models. Consistent with the findings of 
earlier studies (Song \& Witt, 2003; Song et al., 2003; Ayeh \& Lin, 2011), this confirms that previous levels of outbound tourism influence current and future demand for international outbound tourism. Although this effect could be attributed to "word of mouth" effect and/or consumer persistence (or repeat visits), some caution needs to be exercised. The aggregated nature of data does not make it possible to determine if the outbound tourists travel to the same particular destinations. A more disaggregated data in terms of destination-specific demand will be needed to reach a concrete conclusion.

\section{TABLE 1 \\ ESTIMATES OF TOURISM IMPORT DEMAND PARAMETERS (DEPENDENT VARIABLE IS LNTM)}

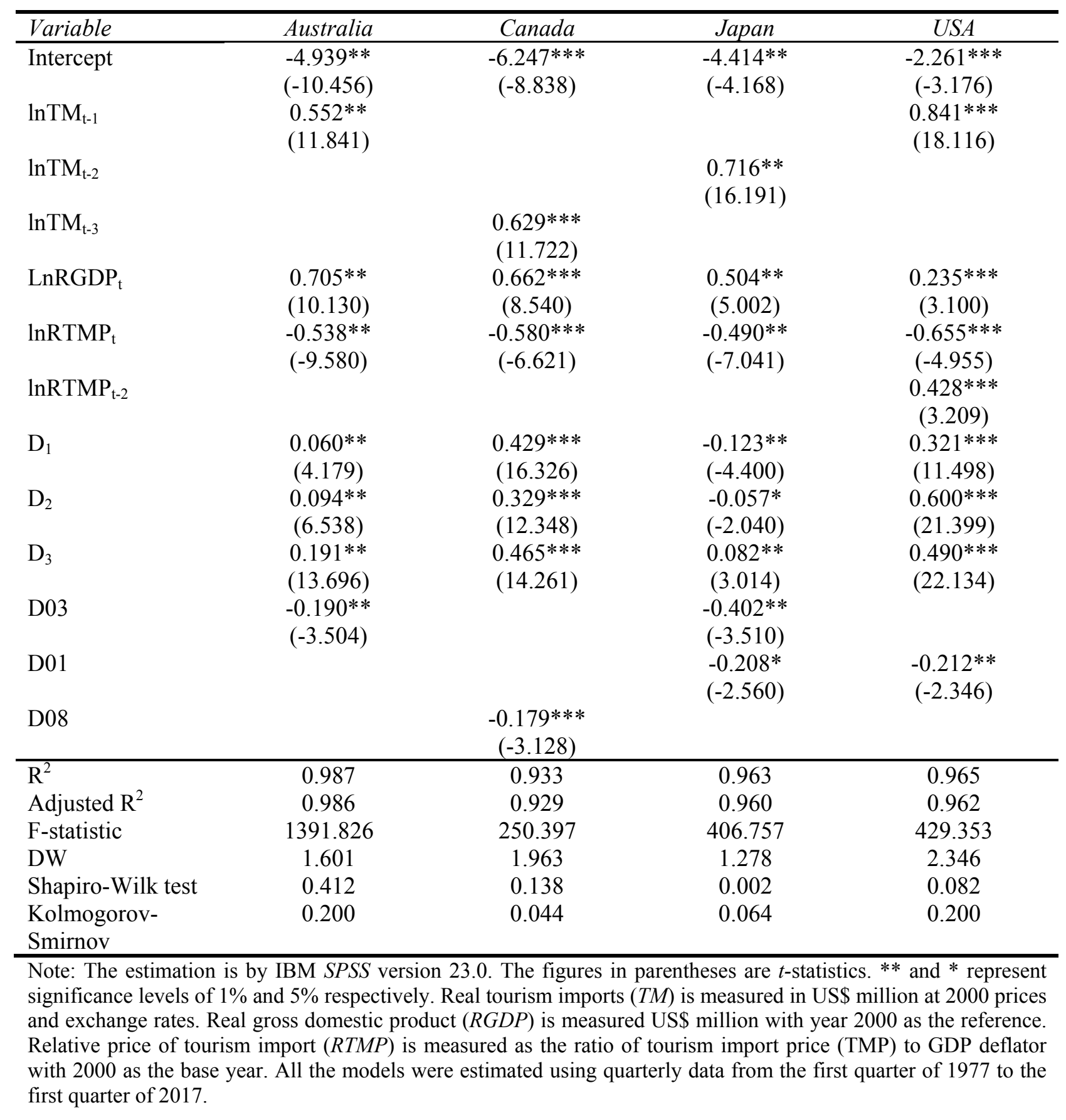


The coefficients of the dummies, SARS, September 11 terrorist attacks and the 2008/2009 global financial crisis are also statistically significant with negative coefficient to show that these one-off events have adverse effect on outbound tourism. It is revealing to note that SARS had adverse effects on the demand for international outbound tourism in Australia and Japan but not in Canada and USA. Also, September 11 terrorist attack had a dampening effect on demand for tourism imports in Japan and USA but not in Canada and Australia. Furthermore, the seasonal dummies are also statistically significant, suggesting that outbound tourism demand has seasonal variations. Except for Japan, the coefficients of all the seasonal dummies are positive. This indicates that demand for international tourism in each of the first three quarters (1,2 and 3) of the year is higher relative to the fourth quarter. This has implications for domestic tourism which is regarded as an important substitute for international outbound tourism (Crouch, 1994; Song \& Witt, 2000). In this regard, to attract people to stay within Australia, Canada and USA, local tourism authorities would have to put in more efforts during the first, second and third quarters of the year than in the fourth quarter of the year. However, for Japan, the converse is the case; greater efforts may be required in the fourth quarter of the year than in the first three quarters as demand for international tourism is typically higher.

\section{Validity of the Models}

Further to the models' high $\mathrm{R}^{2} \mathrm{~s}$ and adjusted $\mathrm{R}^{2} \mathrm{~s}$, significant $\mathrm{F}$-statistics and theoretical validity of the coefficients (see Table 1), the validity of the models' results were tested for compliance with OLS assumptions. First, the seriousness of multicollinearity (which if present, renders otherwise significant coefficients insignificant) was tested using Variance Inflation Factor (VIF) and Tolerance level. The results indicate that there is no serious problem of multicollinearity among the explanatory variables (see Table A1 in the Appendix). Except for Japan, which has two VIFs to be marginally above 10, all other VIFs are below 10 as recommended by Myers (1990). Similarly, nearly all the tolerance levels are higher than 0.1 - the minimum value that calls for concern. Second, the test for heteroscedasticity also failed to reject the null hypothesis of homoscedastic error terms upholding the assumption that the variances of the residuals are constant. The Scatter plot of the regression standardised residuals against the regression standardised predicted values confirms that there is no systematic pattern in the residuals and not more $5 \%$ of the residuals are outside \pm 2 standard deviation of the zero mean (see Figure A1 in the Appendix).

The third diagnostic test suggests the models is free from the problem of autocorrelation since the DW statistics are close to 2 except for Japan which is approximately 1.3. In view of the potential biasedness of the DW statistic in detecting autocorrelation in models with lagged dependent variable(s), the DW may not be reliable and therefore the Durbin-h statistic was resorted to. Finally, the normality of the residuals was tested using Kolmogorov-Smirnov (K-S) and Shapiro-Wilk (S-W) statistics which are corroborated by the histogram and P-P (Q-Q) plots of the regression standardised residual graphs (see Figure A2 in the Appendix). Overall, the distributions of the residuals approximated the standard normal distribution. With most of the assumptions satisfied, the estimated demand equations were then used to calculate the demand elasticities which are reported in the next section.

\section{Demand Elasticities}

Given a pre-specified functional relationship between tourism demand and its explanatory variables such as equation (4), tourism demand elasticities are the quantitative estimates of the degree of sensitivity of tourism demand to changes in the explanatory variables (Song, Kim \& Yang, 2010). The coefficients of price and income variables reported in Table 1 represent short-run elasticities. To obtain the long run elasticities, the following mathematical formulae are applied.

income elasticity of demand $=\sum_{0}^{4} \beta_{i j} /\left(1-\sum_{1}^{4} \alpha_{i j}\right)$ 
price elasticity of demand $=\sum_{0}^{\sum_{0}^{4} \delta_{i j}} /\left(1-\sum_{1}^{4} \alpha_{i j}\right)$

Although the formulae state that the summation is from zero to four, only the coefficients of the variable appearing in the results reported in Table 1 are summed.

Table 2 presents the demand elasticities for the four regression equations. From the results, demand for outbound tourism is price and income elastic in all four countries. This means for a $1 \%$ change in price or income, demand for international tourism import will change by more than one per cent. Price elasticity of demand for international tourism ranges from -1.201 (Australia) to -1.721 (Japan). By contrast, income elasticity of demand ranges from 1.476 (USA) to 1.783 (Canada).

TABLE 2

ESTIMATED DEMAND ELASTICITIES

\begin{tabular}{lll}
\hline Country & Price Elasticity & Income Elasticity \\
\hline Australia & -1.201 & 1.575 \\
Canada & -1.564 & 1.783 \\
Japan & -1.721 & 1.769 \\
USA & -1.430 & 1.476 \\
\hline
\end{tabular}

Relating these finding to previous studies, some measure of consistency can be said to have been achieved. Prior studies (e.g. Smeetaran, 2012a; Smeral, 2011; Lim et al., 2008) have found tourism demand to be price and income elastic. Although the coefficients of the elasticities cannot be compared directly to these studies due to differences in the data frequency, modelling techniques and variables included, it can be noted that the estimates of the elasticities are within reasonable expectations. According to the Economist Intelligence Unit (1972), even though estimated income elasticities may be above 2.0, the normal range is between 1.0 and 2.0.

\section{CONCLUSION AND IMPLICATIONS}

Consistent with previous studies, the empirical analysis in this study has reaffirmed that income and prices are significant predictors of tourism demand (Lim, 1997; Song \& Witt, 2000, Ayeh \& Lin, 2011; Smeral, 2009; 2012; Song \& Witt, 2003; Song et al., 2003; Smeetaran, 2012a; 2012b). The magnitudes of the income elasticity of demand which ranges between 1.476 (USA) and 1.783 (Canada) indicate that tourism import is income elastic and more precisely a luxury commodity than a necessity. Similarly, demand for international outbound tourism is price elastic with values from -1.201 (Australia) to -1.721 (Japan). With these findings, it can be concluded that in the long run, tourism import demand will increase more than proportionately to an increase in real gross domestic product all other factors being equal but decrease more than proportionately to an increase in cost of travelling abroad relative to domestic cost. The significant effects of the dummies also indicate that demand for tourism import is subject to seasonal variations and one-off events.

The conclusions reached in this study offer important implications for practitioners especially destination management organizations. First, outbound tourism is price elastic. This implies that a reduction in domestic price relative to the cost of international tourism import will cause demand for tourism import to decline by a relatively higher proportion. Thus, better price management in the touristgenerating countries considered in this study (i.e. Australia, Canada, Japan and USA) is critical to reducing demand for outbound tourism. Second, while better management of domestic price has the tendency to reduce demand for outbound tourism, improvement in domestic income through appropriate government policies will increase demand for outbound tourism. Third, the statistical significance of the seasonal dummies shows that demand for outbound tourism is subject to seasonal variation, suggesting 
which seasons demand is relatively high or low. For example, in Australia, Canada and USA demand for outbound tourism is higher in the first, second and third quarters of the year relative to the fourth quarter. The implication here is that for policy makers to bring down demand for international outbound tourism, domestic tourism, which is seen as the closest substitute, may be promoted extensively in these quarters.

Although this current study could not include other relevant variables such as immigration requirements as identified by Seetaram (2012a) and Smith and Toms (1978), the findings are nonetheless valid and highly reliable. The application of the general to specific methodology returns high $\mathrm{R}^{2} \mathrm{~s}$ (more than 0.93 for all countries) indicating the goodness of fit of the models. As direction for future research, these variables could be accounted for in the models when data become available. Other areas that the current research could be extended to include determining the elasticities associated with the seasonality.

\section{REFERENCES}

Agnew, M. D., \& Palutikof, J. P. (2006). Impacts of short-term climate variability in the UK on demand for domestic and international tourism. Climate Research, 31(1), 109-120.

Ayeh, J. K., \& Lin, S. (2011). Estimating tomorrow's tourist arrivals: Forecasting the demand for China's tourism using general-to-specific approach. Tourism Hospitality Research, 11(3), 197-206.

Cortés-Jiménez, I. (2009). Estimation of outbound Italian tourism demand: A monthly dynamic ECLAIDs model. Tourism Economics, 15(3), 547-565.

Crouch, G. I. (1994). The study of international tourism demand: A review of findings. Journal of Travel Research, 33(1), 12-23.

Crouch, G. I. (1995). A meta-analysis of tourism demand. Annals of Tourism Research, 22(1), 103-118.

Crouch, G. I. (1996). Demand elasticities in international marketing: A meta-analytical application to tourism. Journal of Business Research, 36(2), 117-136.

Deaton, A. \& Muellbauer, J. (1980). An almost ideal demand system, American Economic Review, 70(3), 312-336.

Eugenio-Martin, J. L., \& Campos-Soria, J. A. (2011). Income and the substitution pattern between domestic and international tourism demand. Applied Economics, 43(20), 2519-2531.

Kulendran, N., \& Wilson, K. (2000). Modelling business travel. Tourism Economics, 6, 47-59.

Kulendran, N., \& Witt, S. F. (2001). Cointegration versus Least Squares Regression. Annals of Tourism Research, 28, 291-311.

Li, G., Song, H., \& Witt, S. F. (2005). Recent developments in econometric modelling and forecasting. Journal of Travel Research, 44(1), 82-89.

Lim, C. (1997). Review of international tourism demand models. Annals of Tourism Research, 24, 835849.

Lim, C. (1999). A meta analytic-review of international tourism demand. Journal of Travel Research, $37(3), 273-284$.

Lim, C. (2004). The major determinants of Korean outbound travel to Australia. Mathematics and Computers in Simulation, 64(3), 477-485.

Lim, C., Min, J. C., \& McAleer, M. (2008). Modelling income effects on long and short haul international travel from Japan. Tourism Management, 29, 1099-1109.

Lorde, T., Li, G., \& Airey, D. (2016). Modeling Caribbean tourism demand: an augmented gravity approach. Journal of Travel Research, 55(7), 946-956.

Martins, L. F., Gan, Y., \& Ferreira-Lopes, A. (2017). An empirical analysis of the influence of macroeconomic determinants on World tourism demand. Tourism Management, 61, 248-260.

Mikulicz, H. (1983). Determinants of tourism flows in Europe. In Seminar on the importance of research in the tourism industry. Helsinki (Finland) 8th-11th June 1983 (pp. 7-16). ESOMAR, European Society for Opinion and Marketing Research.

Myers, R. (1990) Classical and modern regression with applications (2 ${ }^{\text {nd }}$ ed.). Boston, MA: Duxbury.

Pham, T. D., Nghiem, S., \& Dwyer, L. (2017). The determinants of Chinese visitors to Australia: A dynamic demand analysis. Tourism Management, 63, 268-276.

74 Journal of Applied Business and Economics Vol. 21(3) 2019 
Seetaram, N. (2012a). Estimating demand elasticities for Australia's international outbound tourism. Tourism Economics, 18(5), 999-1017.

Seetaram, N. (2012b). Immigration and tourism demand: Empirical evidence from Australia. Tourism Management, 33(6), 1535-1543.

Smeral, E. (2009). The Impact of the financial and economic crisis on european tourism. Journal of Travel Research, 48(1), 3-13.

Smeral, E. (2010). Impacts of the world recession and economic crisis on tourism: Forecasts and potential risks. Journal of Travel Research, 49(1), 31-38.

Smeral, E. (2012). International tourism demand and business cycle. Annals of Tourism Research, 39(1), 379-400.

Smith, A. B., \& Toms, J. N. (1978). Factors affecting demand for international travel to and from Australia. Occasional paper, 11, Bureau of Transport, Canberra.

Song, H., \& Li, G. (2008). Tourism demand modelling and forecasting--A review of recent research. Tourism Management, 29, 203-220.

Song, H., \& Witt, S. F. (2000). Tourism demand modelling and forecasting: Modern econometric approches. Cambridge: Pergamon.

Song, H., \& Witt, S. F. (2003). Tourism forecasting: The general-to-specific approach. Journal of Travel Research, 42(1), 65-83.

Song, H., \& Wong, K. (2003). Tourism demand modelling: A time-varying parameter approach. Journal of Travel Research, 42(1), 57-64.

Song, H., Kim, J. H., \& Yang, S. (2009). Confidence intervals for tourism demand elasticity. Annals of Tourism Research, 37(2), 377-396.

Song, H., Romilly, P., \& Liu, X. (2000). An empirical study of outbound tourism demand in the UK. Applied Economics, 32, 611-624.

Song, H., Wong, K. K., \& Chon, K. K. (2003). Modelling and forecasting the demand for Hong Kong tourism. International Journal of Hospitality Management, 22, 435-451.

Tang, C. F., \& Tan, E. C. (2016). The determinants of inbound tourism demand in Malaysia: another visit with non-stationary panel data approach. Anatolia, 27(2), 189-200.

Tavares, J. M., \& Leitão, N. C. (2017). The determinants of international tourism demand for Brazil. Tourism Economics, 23(4), 834-845.

Vanhove, N. (1980). Forecasting in tourism. The Tourist Review, 3, 2-7.

Witt, S. F., \& Witt, C. A. (1992). Modelling and forecasting demand in tourism. London: Acadmic Press.

Witt, S. F., \& Witt, C. A. (1995). Forecasting tourism demand: A review of empirical research. International Journal of Forecasting, 11(3), 447-475. 


\section{APPENDIX}

TABLE A1

MULTICOLLINEARITY STATISTICS

\begin{tabular}{|c|c|c|c|c|c|c|c|c|}
\hline \multirow[t]{2}{*}{ Variable } & \multicolumn{2}{|c|}{ Australia } & \multicolumn{2}{|c|}{ Canada } & \multicolumn{2}{|c|}{ Japan } & \multicolumn{2}{|c|}{ USA } \\
\hline & Tolerance & $V I F$ & Tolerance & $V I F$ & Tolerance & VIF & Tolerance & VIF \\
\hline $\operatorname{lnTM}_{\mathrm{t}-1}$ & 0.048 & 20.707 & & & & & 0.128 & 7.810 \\
\hline $1 \mathrm{nTM}_{\mathrm{t}-2}$ & & & & & 0.142 & 7.058 & & \\
\hline $1 \operatorname{lnTM}_{\mathrm{t}-3}$ & & & 0.200 & 4.989 & & & & \\
\hline $1 \mathrm{nRGDP}_{\mathrm{t}}$ & 0.039 & 25.636 & 0.203 & 4.936 & 0.165 & 6.076 & 0.118 & 8.491 \\
\hline $1 \mathrm{nRTMP}_{\mathrm{t}}$ & 2.63 & 3.807 & 0.701 & 1.427 & 0.596 & 1.679 & 0.159 & 6.279 \\
\hline $1 \operatorname{lnRTMP}_{\mathrm{t}-2}$ & & & & & & & 0.161 & 6.222 \\
\hline D1 & 0.537 & 1.863 & 0.638 & 1.568 & 0.631 & 1.585 & 0.386 & 2.590 \\
\hline D2 & 0.523 & 1.912 & 0.632 & 1.583 & 0.650 & 1.539 & 0.390 & 2.562 \\
\hline D3 & 0.560 & 1.785 & 0.423 & 2.365 & 0.666 & 1.501 & 0.613 & 1.630 \\
\hline D01 & & & & & 0.965 & & 0.942 & 1.062 \\
\hline D03 & 0.955 & 1.048 & & & & & & \\
\hline D08 & & & 0.878 & 1.139 & & & & \\
\hline
\end{tabular}

FIGURE A1

HETEROSCEDASTICITY TEST WITH SCATTER PLOT
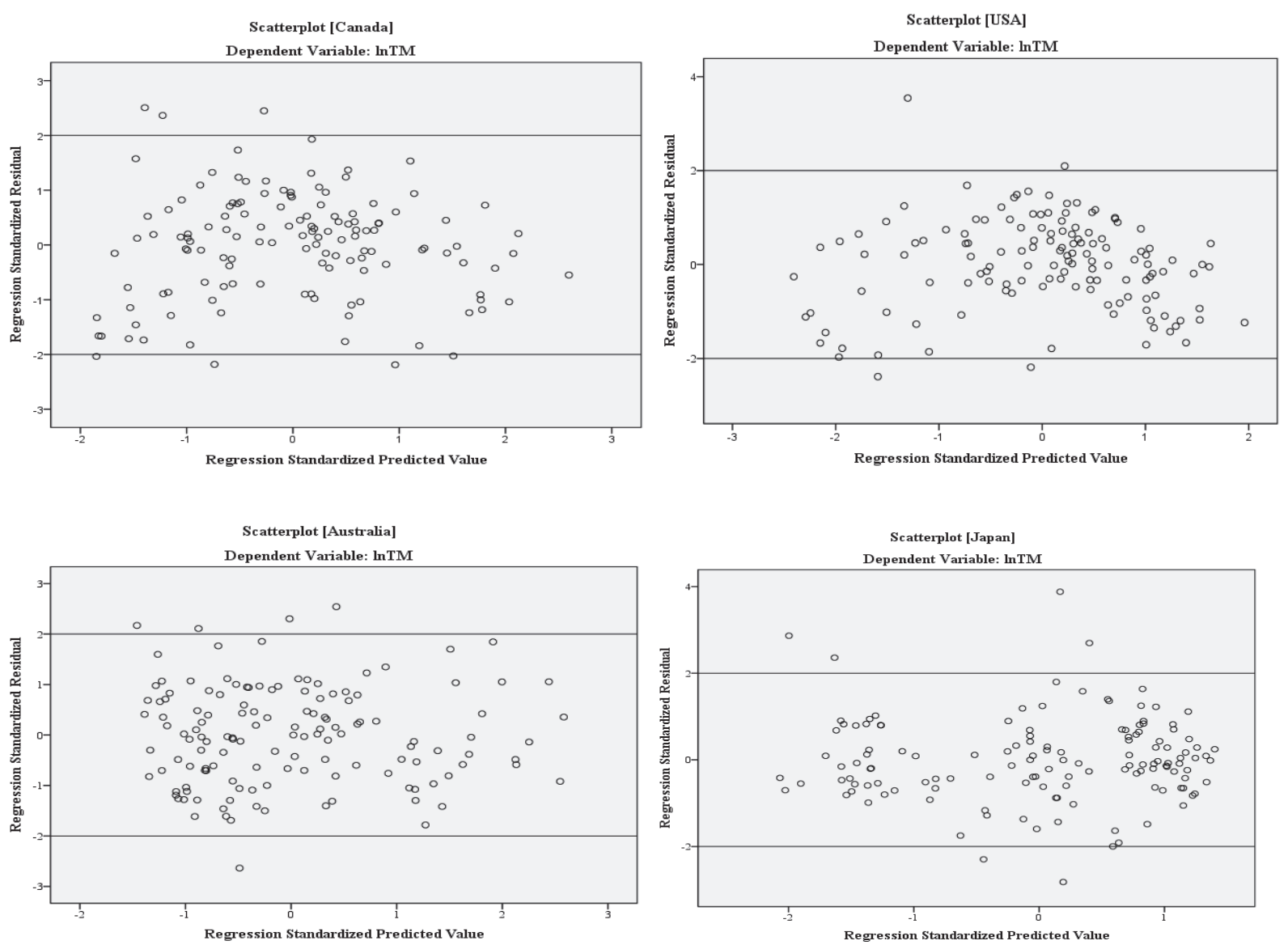

76 Journal of Applied Business and Economics Vol. 21(3) 2019 
FIGURE A2

NORMALITY TEST WITH HISTOGRAM AND P-P (Q-Q) PLOT
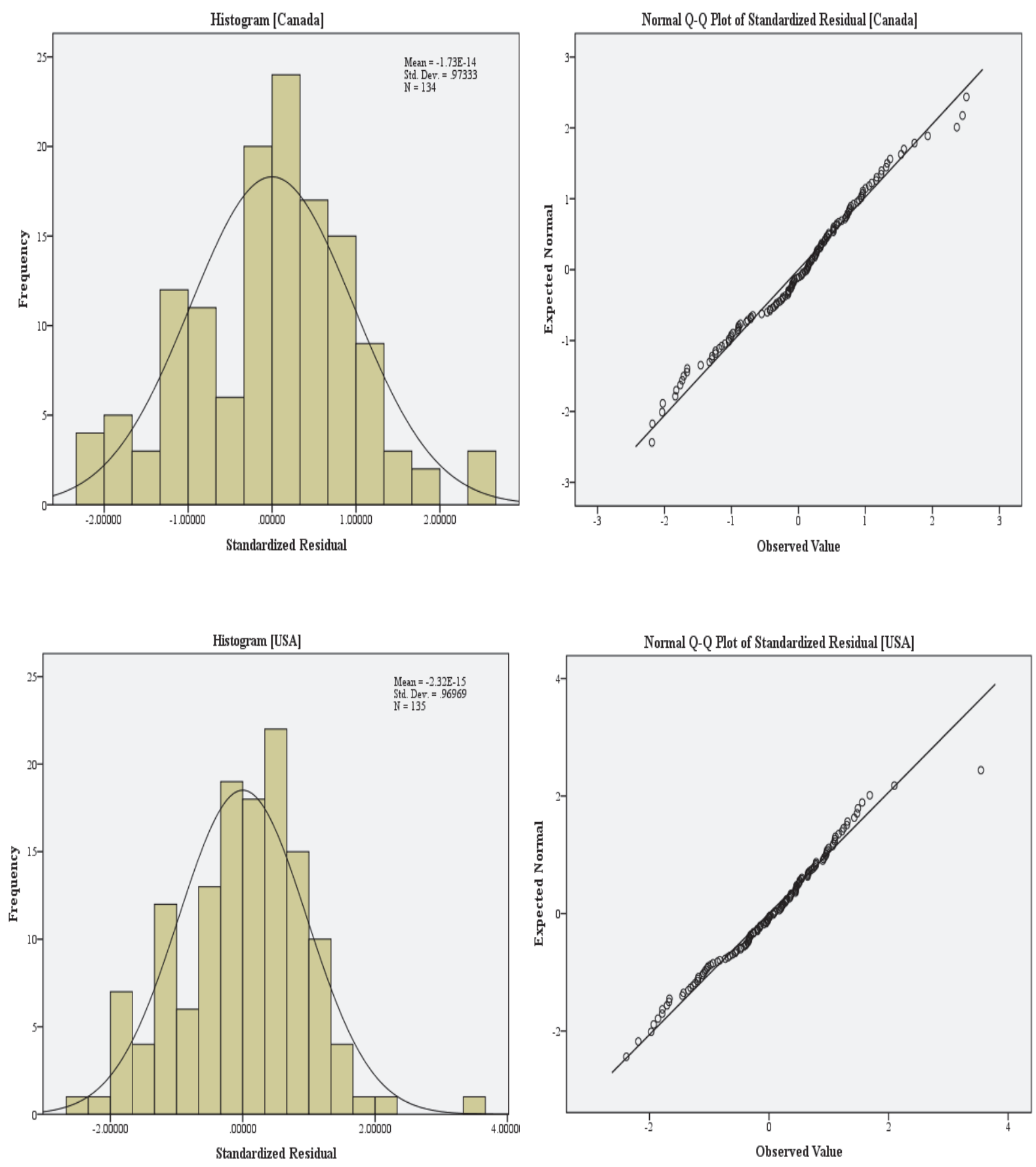

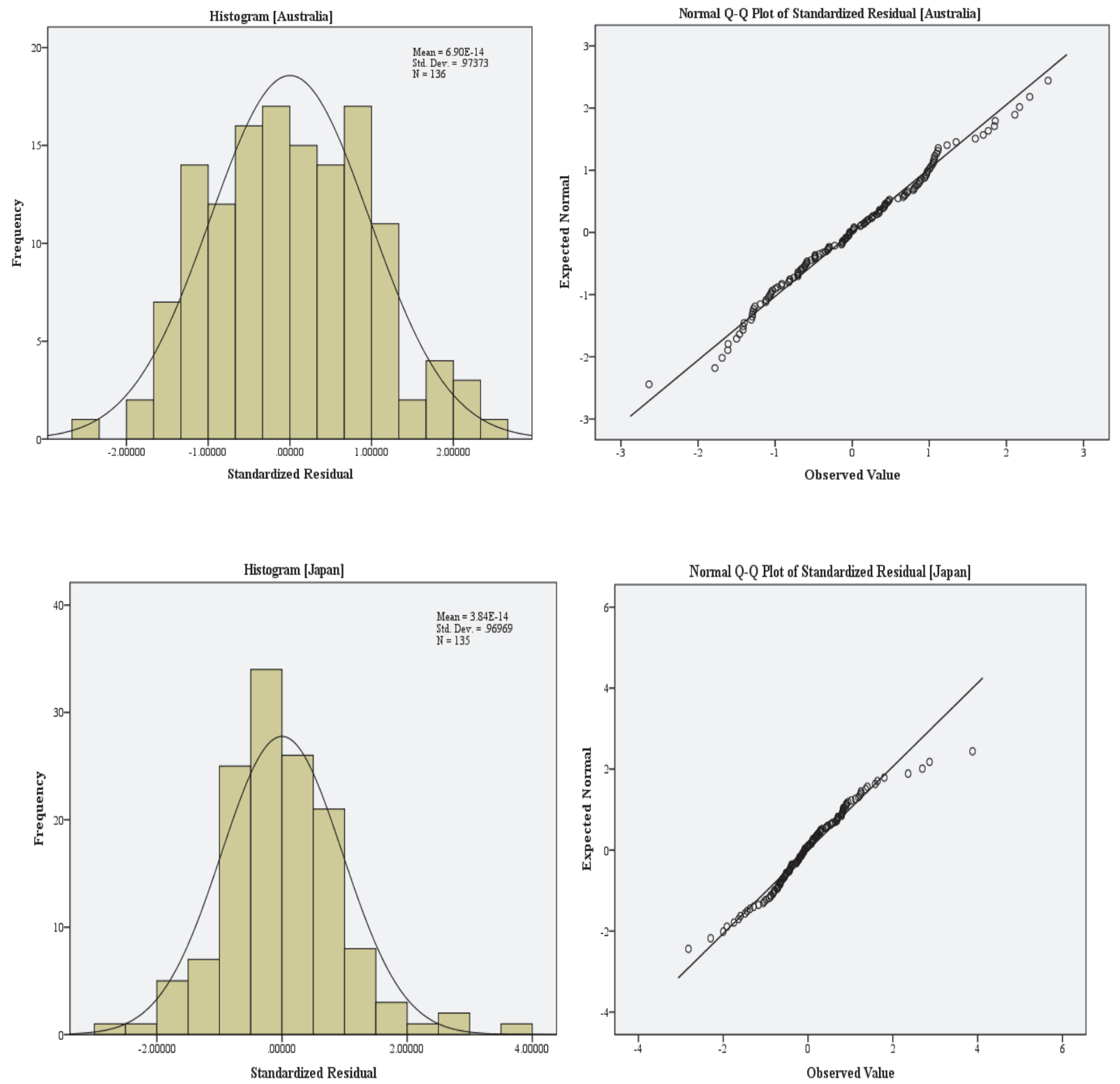